V.P.Shpachuk ${ }^{1}$, orcid.org/0000-0002-1714-8648, M. A. Zasiadko ${ }^{1}$, orcid.org/0000-0001-6725-3385, T. O. Suprun ${ }^{1}$, orcid.org/0000-0002-9666-5909, V.V. Dudko ${ }^{2}$

\title{
VARIATION COEFFICIENT OF TORSIONAL VIBRATIONS OF THE CONNECTION NODES OF VIBRATING MACHINES
}

Purpose. To formalize the dependence of the eigenfrequencies of translational and torsional vibrations of the structural elements of the vibrating machine articulated by the connection node on their design parameters and mechanical characteristics, as well as regulatory requirements for vibration activity, strength and accuracy. To develop a method for selecting the design parameters of the elastic band element of the package, taking into account the specified values of the amplitude and frequency characteristics of the dynamic loads reproduced by the supporting structure and the coefficient of variation of the natural frequencies of translational and torsional vibrations.

Methodology. The research is based on fundamental approaches of applied mechanics, machine dynamics and vibration reliability.

Findings. The dependences of the eigenfrequencies of torsional vibrations of the body parts of the vibrating machine connected by the connection node on their design parameters and mechanical characteristics are obtained and analyzed. Vibrations around an axis orthogonal to the working direction of the node are considered. A comparative analysis of the natural frequencies of the node in the direction of the transmitted vibration and its circular vibrations from the design parameters and mechanical characteristics of the elastic band elements, their number in the package and the number of packages in the connection node is performed.

Originality. It is in the fact that for the first time the dependences describing the natural frequencies of translational and torsional vibrations of the body parts of a vibrating machine, articulated by a package of elastic band elements, are obtained. Also the paradigm for the choice of design parameters and mechanical characteristics of the elastic band element of the package, which is based on the results of a comparative analysis of the eigenfrequencies of vibrations in the working and connected directions through their coefficient of variation is innovative. This made it possible to include the criterion of vibration reproduction accuracy, which is formalized through the coefficient of frequency variation, together with the criteria of strength and rigidity, in the methodology of synthesis of the structural scheme of the vibrating machine.

Practical value. The proposed methodological solutions for the calculation and selection of design parameters and mechanical characteristics of tape elastic elements ensure the achievement of vibration activity indicators of articulated parts, as well as the ratio of natural vibration frequencies in the working and related directions at the level of the requirements of normative documents when upgrading existing machines and creating new modern equipment. As a result, the reliability, durability, safety, productivity and load-bearing capacity of machines, equipment and mechanisms of mining engineering, aviation, transport and space technology are increased.

Keywords: torsional vibrations, connection nodes of the vibration stand, vibration loads, elastic tape element, vibrating machines

Introduction. Vibrating machines are widely used in the national economy [1], it is due to their high functional, technological, and energy efficiency [2]. In mining machinery these are the working units of machines for laying the main and auxiliary drifts and tunnels during mining [3]. And in transport [4], aviation and space technology [5], their purpose is to conduct bench tests of modernized or newly created machine components for vibration reliability and stability of functioning [6].

In this paper, the object of research involves vibration machines that reproduce the vibrations of the platform simultaneously in the horizontal and vertical directions. This makes their use more efficient compared to machines of a similar purpose, whose working body performs only unidirectional vibrations [7]. The technical product name of the specified body part in the field of fatigue strength and vibration reliability is the platform of a two-coordinate vibration stand. In the future, as the analyzed vibration machine, we will specifically understand the stand of two-coordinate vibration for mechanical tests of objects for stability of functioning and strength.

Therefore, the problem of creating nodes for connecting multi-coordinate vibration stands is one of the most relevant in modern science and technology.

Status of the issue. It is practically shown that in a number of special-purpose vibrating machines, the body parts of the base units perform two-coordinate vibrations during operation. These are vibrations, for example, simultaneously in the

(c) Shpachuk V. P., Zasiadko M. A., Suprun T. O., Dudko V.V., 2021 vertical and horizontal plane. In this case, they are subjected, taking into account the unbalanced moments arising from the inertia forces of moving parts, to the action of parasitic torsional vibrations [8]. The latter reduce the accuracy of reproduction of a given two-coordinate vibration, both in magnitude and in direction. This negatively affects the reliability of the determined indicators of vibration reliability of objects in operation. The performance and safety of the vibration machine are also reduced.

Practically, various methods are used to eliminate the shortcomings. These are active, passive or combined methods [8] based on the use of special blocks and nodes. However, for some types of connection nodes, made, for example, in the form of packages of flat elastic elements, the known approaches require modernization and improvement due to the peculiarities of the structural layout of vibration machines.

In well-known papers, theoretical [9] and practical [10] issues related to the problem of creating and calculating the nodes of vibrating machines have been solved. At the same time, there is a lack of an integrated approach to the process of creating a vibrating machine that simultaneously fulfills the specified requirements for rigidity and strength [11] of elastic elements, as well as simultaneously for the accuracy of reproducing the specified vibrations of the working body.

Purpose. To formalize the dependence of the eigenfrequencies of torsional vibrations of the body parts of the vibrating machine articulated by the connection node on their structural and mechanical parameters, as well as regulatory requirements for vibration activity and strength. Vibrations 
around an axis orthogonal to the working direction of the node are considered. The dependences on the radius of the roller of its tension block, the thickness of the elastic band element and the permissible vibration dynamic characteristics of the machine components in the working and conjugate directions are analyzed in detail.

To introduce a normative parameter - the coefficient of variation of the eigenfrequencies of translational and torsional vibrations of the connection node - into the paradigm of the process of creating a vibration machine. To analyze its dependence on the geometric parameters of the structural parts of the connection node.

To develop a method for selecting the structural and mechanical parameters of the analyzed elastic tape element of the package, taking into account the regulatory requirements for the value of the variation coefficient of the eigenfrequencies of translational and torsional vibrations of the connection node.

Results. In the paper, the basic design element of the vibrating machine is the package nodes connecting the body parts with each other, as well as a fixed base. Their application makes it possible to create, for example, a stand of two-coordinate linear (translational) vibration, which is an important link in the chain of laboratory tests of components and blocks of new machines for vibration reliability. In this case, the mechanical loading of the test object best meets the actual operating conditions. The design scheme of the vibrating machine on the example of a two-coordinate vibration stand is shown in Fig. 1. Here: 1, 2- horizontal and vertical vibration generators of the stand; 3, 4- body parts of the horizontal 1 and vertical 2 vibration generators of the stand; 5 - body parts of the stand platform; 6-9- auxiliary body parts; $10-13$ - the main vibration transmission connection nodes; $14-17$ - auxiliary connection nodes. The platform of the two-coordinate vibration stand is not shown in the drawing. In the diagram, the auxiliary body parts and auxiliary connection units are designed to reduce parasitic torsional vibrations of the stand parts $3-5$.

That is why it is important to investigate the formalization of the eigenfrequencies of the incoming vibrations of the body parts $f_{n}$ articulated by the connection node in the direction of the axis of the cylindrical elastic element, as well as the frequencies $f_{k}$ of the circular vibrations - around the axis perpendicular to the previously specified one. Their comparative analysis with the use of the coefficient of variation of the natural frequencies of useful translational and parasitic circular vibrations allows us to formulate requirements for the choice of design parameters of the analyzed elastic band element of the package. Here, the specified values of the fatigue strength margin coefficient are taken into account at the same time as well

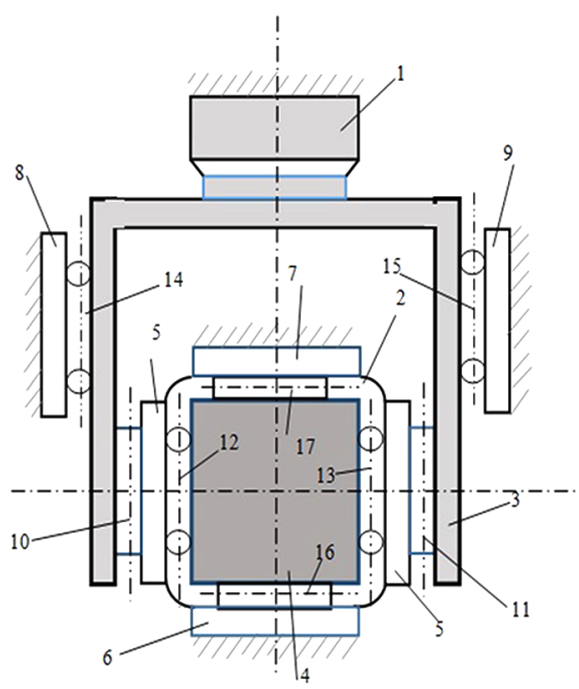

Fig. 1. Vibration machine diagram as the parameters of the amplitude and frequency characteristics of dynamic loads reproduced by the supporting structure. Moreover, the parasitic torsional vibrations that actually occur in this case are taken into account.

To analyze the eigenfrequencies of linear and torsional vibrations connected by the junction of body parts, consider its generalized mechanical scheme, shown in Fig. 2, taking into account [6]. Here: 1,2 - body parts, articulated by the joint unit; 3 - elastic elements simulating the stiffness $c_{n}$ characteristics of each of the two packages of the joint unit in the direction of the axis $O_{y} ; 4$ - rods that model the rollers of tension devices. In Fig. 2: $l_{1,2,3}-$ geometric characteristics of the connection node; $\varphi, \varepsilon, M^{P}, M^{\varphi}$ - kinematic parameters, moment force factors of the reactions of elastic elements bonds of the node 3 and the Dalembert inertia forces.

Taking into account the results of [6], the axial stiffness of one of the two packages of the junction node is defined as

$$
\begin{gathered}
c_{n}=n /\left(\mu(2 a+\pi r) / G A+\left(2 a^{3} / 3+\pi r a^{2} / 2+\right.\right. \\
+4 r^{2} a / 3+\pi r^{3} / 8-\left(a^{2}+\mathrm{pra} / 2+2 r^{2} / 3\right) /(2 a+ \\
\left.\left.+\pi r / 2)\left(2 a^{2}+\pi r a+4 r^{2} / 3\right)+(2 a+\pi r)^{2}(2 a+\pi r / 2)\right)\right) / E I_{z},
\end{gathered}
$$

where $n$ is the number of tapes in the package; $A=b \cdot h$ and $I_{z}=\frac{b h^{3}}{12}$ are the area and moment of inertia of the elastic band section; $a, b, h, r, E, G, \mu$ are linear dimensions of the tape and elastic characteristics of the tape material.

From (1), the eigenfrequency of translational vibrations of the housing part 1 in Fig. 2, mass $m$, in the direction of the $O_{y}$ axis will be

$$
f_{n}=\frac{1}{2 \pi}\left(\frac{2 c_{n}}{m}\right)^{\frac{1}{2}} .
$$

To find the eigenfrequency $f_{k}$ of torsional vibrations of the body part 1 around the axis $O_{z}$, the d'Alembert principle is applied

$$
M^{\varphi}+M^{P}=0,
$$

where $M^{\varphi}=-I_{z} \varepsilon$ is the moment of d'Alembert's inertia forces; $I_{z}$ is the moment of inertia of the part 1 relative to the axis $O_{z}$; $\varepsilon$ is angular acceleration; $M^{P}$ is the moment of reactions of connections.

Let us assume that the center of mass of the body part 1 (Fig. 2) coincides with the pole of the coordinate system $x y z$. Then for the scheme shown in Fig. 2, one has

$$
M^{p}=\frac{c_{n} \Delta l_{1}}{2}+\frac{c_{n} \Delta l_{1}}{2}=c_{n} \Delta l_{1},
$$

where $\Delta$ is axial deformation of elastic elements 3 .

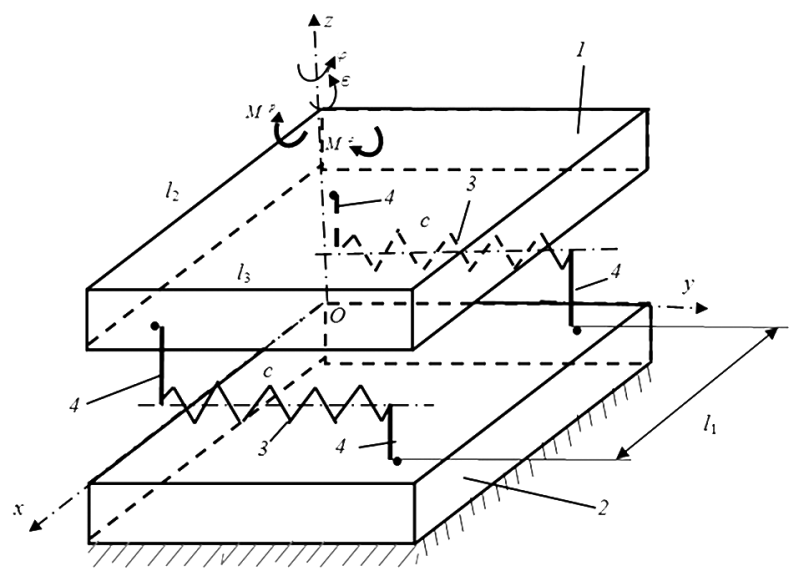

Fig. 2. Generalized mechanical chart of the vibration machine connection node 

we get

In the field of small elastic deformations $\Delta=\frac{\varphi \cdot l_{1}}{2}$. Then

$$
M^{p}=\frac{c_{n} \varphi \cdot l_{1}^{2}}{2} .
$$

Differential equation of free vibrations of part 1 around the axis $O z$ has the form

$$
I_{z} \ddot{\varphi}+\left(\frac{c_{n} \cdot l_{1}^{2}}{2}\right) \cdot \varphi=0,
$$

where $I_{z}=\frac{m\left(l_{2}^{2}+l_{3}^{2}\right)}{12}$ is the inertia momentum of the mass of the part 1 in the diagram in Fig. 2. We introduce the notation in (3) $c_{k}=\frac{c_{n} \cdot l_{1}^{2}}{2}$ is torsional stiffness of the connection node. Then the natural frequency of torsional vibrations of the node is determined by the expression

$$
f_{k}=\frac{1}{2 \pi}\left(\frac{c_{k}}{I_{z}}\right)^{\frac{1}{2}}=\frac{1}{2 \pi}\left[\frac{c_{n} l_{1}^{2} / 2}{m\left(l_{2}^{2}+l_{3}^{2}\right) / 12}\right]^{\frac{1}{2}}=\frac{1}{2 \pi}\left\{\frac{6 c_{n} l_{1}^{2}}{m\left(l_{2}^{2}+l_{3}^{2}\right)}\right\}^{\frac{1}{2}} .
$$

Taking (2) into account, the formula for determining the eigenfrequencies of torsional vibrations will take the form

$$
f_{k}=\frac{1}{2 \pi}\left[\frac{2 c_{n}}{m}\right]^{\frac{1}{2}} \cdot\left[\frac{3 l_{1}^{2}}{l_{2}^{2}+l_{3}^{2}}\right]^{\frac{1}{2}}
$$

Finally, one gets

$$
f_{k}=f_{n}\left[\frac{3 l_{1}^{2}}{l_{2}^{2}+l_{3}^{2}}\right]^{\frac{1}{2}} .
$$

Further, taking into account ( 2 and 4 ), we will conduct a graphical analysis of the frequencies of translational and torsional vibrations behavior of the part 1 of the connection node, depending on the thickness $b$ of the elastic element and its radius of curvature $r$.

For this purpose, hereinafter, one is taking the following design parameters and mechanical characteristics of the connection node in Fig. $2: m=5 \mathrm{~kg} ; l_{1}=0.18 \mathrm{~m} ; l_{2}=0.2 \mathrm{~m} ; l_{3}=0.1 \mathrm{~m}$; $\mu=1.2 ; b=\left[1 \cdot 10^{-4}-3 \cdot 10^{-4}\right] \mathrm{m} ; h=14 \cdot 10^{-2} \mathrm{~m} ; a=0.3 \mathrm{~m} ; r=$ $=\left[0.5 \cdot 10^{-2}-2 \cdot 10^{-2}\right] \mathrm{m} ; n=10 ; E=2 \cdot 10^{11} \mathrm{~Pa} ; G=0.4 E$.

Dependencies $f_{n}(b ; r)$ and $f_{k}(b ; r)$ are shown in Fig. 3.

The analysis of the graphs shows the following:

1. Change in the radius of the elastic element in the range $r=\left[0.5 \cdot 10^{-2}-2 \cdot 10^{-2}\right] \mathrm{m}$, for example, with the thickness of the tape $b=1.4 \cdot 10^{-4} \mathrm{~m}$ leads to a change in the eigenfrequencies of translational and torsional vibrations of the connection node in the range $f_{n}=[581-1006] \mathrm{Hz}$ and $f_{k}=[810-1403] \mathrm{Hz}$, that is, to their increase by 1.73 times.

2. It is also established that the increase in the thickness of the tape in the range of $b=\left[1 \cdot 10^{-4}-3 \cdot 10^{-4}\right] \mathrm{m}$ at the radius of the elastic element $r=2 \cdot 10^{-4} \mathrm{~m}$ leads to a change in the eigenfrequencies in the range of $f_{n}=[1114-690] \mathrm{Hz}$ and $f_{k}=$ $=[1555-961] \mathrm{Hz}$, that is, to their reduction by 1.61 and 1.62 times.

With reference to the considered class of vibrating machines, the method for creating two coordinate vibration stands includes the multicriteriality of the basic synthesis problem considered in [12], which are to be maintained when designing their connection nodes. This is, first of all, a stiffness criterion related to the range of operating frequencies of translational vibrations

$$
f_{n} \geq f_{n}^{*},
$$

where $f_{n}^{*}$ is lower value of working frequency set by a normative document.
Also a criterion related to the problem of fatigue strength by equivalent stresses in the material of the elastic band elements of the node [6]

$$
\sigma \leq k \sigma_{-1},
$$

where $\sigma_{-1}$ is endurance limit of the tape material; $k$ is the fatigue strength margin factor.

In the paper, the listed technically feasible criteria of the methodology should be closely linked to the condition of the accuracy of reproducing translational two-coordinate vibration

$$
f_{k} \geq k_{f} f_{n}^{*}
$$

where $k_{f}$ is the coefficient of variation of eigenfrequencies.

The implementation of the proposed criterion for creating a vibrating machine provides levels of parasitic torsional vibrations of the working body that do not exceed the maximum permissible values.

This effect is achieved by a rational choice of mechanical characteristics and geometric parameters of the body parts of the connection node. Further, let us consider the frequency response for the accepted design and mechanical parameters of the connection node of translational $W_{n}(\omega)$ and torsional $W_{k}(\omega)$ vibrations in the direction of the axis $y$ and around the axis $O_{z}$, respectively.

Taking into the account [13], one gets

$$
\begin{aligned}
& W_{n}(\omega)=\frac{1}{m\left|\frac{c}{m-\omega^{2}}\right|} ; \\
& W_{k}=\frac{1}{I_{z} \mid \frac{c_{k}}{I_{z}-\omega^{2} \mid},},
\end{aligned}
$$

where $c=2 c_{n} ; c_{k}=\frac{c_{n} l_{1}^{2}}{2} ; \omega$ is the cyclic frequency of the external force applied to the part.

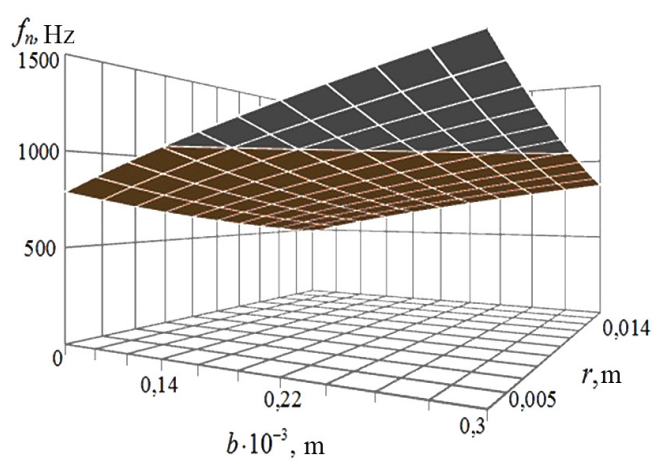

$a$

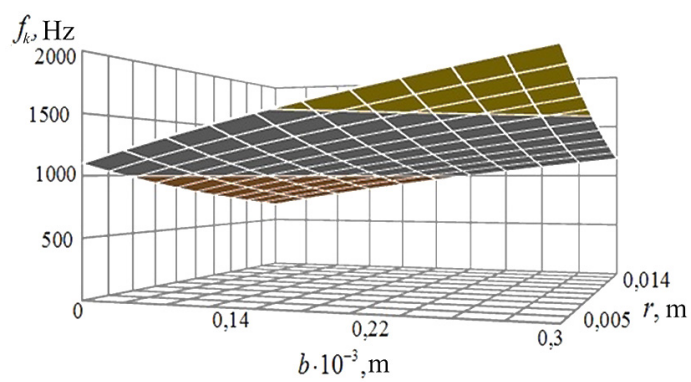

$b$

Fig. 3. Eigenfrequencies of connection nodes:

$a-$ translational $_{n} ; b-$ torsional $f_{k}$ vibrations 
Dependencies $W_{n}(\omega)$ and $W_{k}(\omega)$, for example, when $c=$ $=71 \mathrm{MN} / \mathrm{m}$, are shown in Fig. 4 .

Here $\omega_{0 n}=\left(\frac{c}{m}\right)^{\frac{1}{2}}: \quad \omega_{0 k}=\left(\frac{c_{k}}{I_{z}}\right)^{\frac{1}{2}}$ are eigenfrequencies of the translational and torsional vibration connection nodes.

The analysis of the graphs shows that the frequency $\omega_{0 n}=5500 \mathrm{rad} / \mathrm{s}$, and the frequency $\omega_{0 k}=7500 \mathrm{rad} / \mathrm{s}$, that is, the natural frequency of torsional vibrations of the connection node is 1.36 times greater than the frequency of translational vibrations.

Taking into account the approach described in [11], we further estimate the dependence of the variation coefficient $k_{f}$ of the eigenfrequencies from the geometric parameters of the connection node used in the paper are shown in Fig. 2.

Considering the expressions (2, 4 and 5), we get

$$
k_{f}=\frac{f_{k}}{f_{n}}=\left(\frac{3 l_{1}^{2}}{l_{2}^{2}+l_{3}^{2}}\right)^{\frac{1}{2}} .
$$

The dependence of the coefficient of variation of eigenfrequencies is shown in Fig. 5. Here, the following ranges of changes in the linear dimensions of the parts of the connection unit are accepted: $l_{1}=[0.1-0.3] \mathrm{m} ; l_{2}=1.1 l_{1} \mathrm{~m} ; l_{3}=[0.05-$ $0.15] \mathrm{m} ; h=0.9 l_{3} \mathrm{~m}$.

Graph analysis shows the following:

1. Changing the transverse base of the package connection node in the range $l_{1}[0.1-0.3] \mathrm{m}$ at the longitudinal base (width of the elastic element of the node), for example $h=0.09 \mathrm{~m}$, leads to a change in the coefficient of variation of eigenfrequencies in the range of $k_{f}=[0.67-0.87]$, i. e. to increasing it by 1.3 times.

2. Changing the width of the elastic element of the package in the range of $h=[0.045-0.135] \mathrm{m}$ at the transverse base of the node $l_{1}=0.2 \mathrm{~m}$ leads to a change in the coefficient of variation of natural frequencies in the range of $k_{f}=$ [0.89-0.77], that is, to reducing it by 1.19 times.

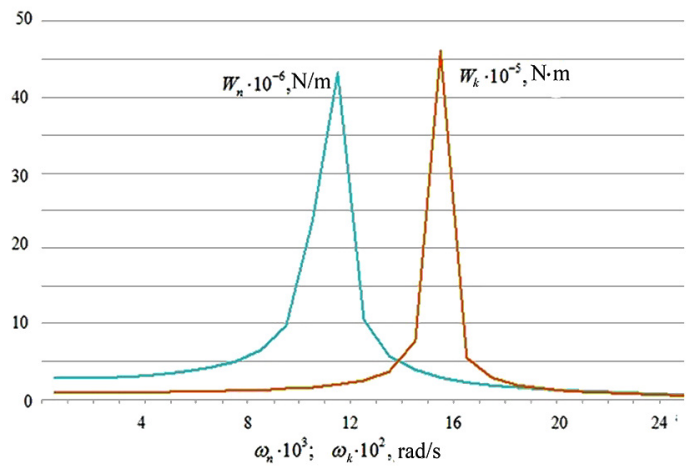

Fig. 4. Frequency response of the connection node



Fig. 5. The coefficient of variation of the connection node eigenfrequencies
Conclusions. The investigation data show that the ability for a targeted values correction of eigenfrequencies of translational and torsional vibrations by rationally choosing the linear dimensions of the elements of its structural scheme parts, taking into account the structure of the expression (6). The process of diluting the eigenfrequencies of the forward and torsional vibrations provides in practice a reduction in the influence of the latter on the reproducible translational vibration in each of the working directions of the machine. It is shown that the set of classical criteria for creating a working vibration machine, including the requirements for rigidity and strength, can be rationally supplemented with the condition for the accuracy of the vibration process reproduction by its operational part. At the same time, the expediency of using the variational coefficient of the eigenfrequencies of translational and torsional vibrations of the machine connection nodes is justified as the analyzed criterion indicator of accuracy.

\section{References.}

1. Peterson, C. (2013). Time-to-failure testing using single- and multi-axis vibration. Sound and Vibration, 47(3), 13-17.

2. Lanets, O. S., Borovets, V. M., \& Derevenko, I. A. (2018). Determination of drivepower of vibrating machines with power and kinematic perturbation. Vibrations in engineering and technology, 3(90), 53-61.

3. Kovalevsra, I., Samusia, V., Kolosov, D., Snihur, V., \& Pysmenkova, T. (2020). Stability of the overworked slightly metamorphosed massif around mine working. Mining of Mineral Deposits, 14(2), 43-52. https://doi.org/10.33271/mining14.02.043.

4. Batt, G. (2016). Simultaneous Multi-Translational-Axis Motion used in the Evaluation of Product Component Frequency Response and Unit Load Stability. International Journal of Advanced Packaging Technology, 4(1), 200-215.

5. Roberts, C., \& Ewins, D. (2018). Multi-axis vibration testing of an aerodynamically excited structure. Journal of Vibpation and Control, 24(2), 427-437. https://doi.org/10.1177/1077546316642064.

6. Shpachuk, V.P. (2018). Synergetic effect in the dynamics of multidimensional mechanical systems: monograph. Kharkiv: KhNUMHim. O. M. Beketova.

7. Laura D. Jacobs, Garrett D. Nelson, \& John H. Hofer (2016). Responses of Structures to SDoF vs. MDoF Vibration Testing. Sensors and Instrumentation, 5, 83-94.

8. Homišin, J. (2016). Characteristics of pneumatic tuners of torsional oscillation as a result of patent activity. Acta Mechanica et Automatica, 10(4), 316-323.

9. Kharchenko, Y., \& Dragun, L. (2017). Mathematical modeling of unsteady processes in electromechanical system of ring-ball mill. $\mathrm{Di}$ agnostyka, 18(1), 25-35.

10. Breslavsky, D., Chuprynin, A., Morachkovsky, O., Tatarinova, O., \& Pro, W. (2019). Deformation and damage of nuclear power station fuel elements under cyclic loading. Journal of Strain Analysis for Engineering Design, 54(5-6), 348-359.

11. Govorov, P. P., Novskiy, V. O., Govorov, V. P., \& Kindinova, A. K. (2020). Management of modes of distributive electric networks of cities under conditions of weak correlation of graphics of active and reactive power. Tekhnichna elektrodynamika, 4, 60-66. https://doi. org $/ 10.15407 /$ techned2020.04.060.

12.Vynohradov, B. V., Homišin, J., \& Kchristenko, A. V. (2016). Limitation of dynamic loads in machine drives. Diagnostyka, 17(2), 35-41. 13. Hursky, V., Kuzio, I., \& Korendiy, V. (2018). Optimal synthesis and implementation of resonant vibratory systems. Universal Journal of Mechanical Engineering, 6(2), 38-46. https://doi.org/10.13189/ ujme.2018.060202.

\section{Коефіцієнт варіації крутильних коливань вузлів з'єднання вібраційних машин}

\section{В. П. Шиачук ${ }^{1}$, М.А. Засядько ${ }^{1}$, Т. О. Супрун ${ }^{1}$, В. В. Дудко}

1 - Харківський національний університет міського господарства імені О.М.Бекетова, м. Харків, Україна, e-mail: v.p.shpachuk@gmail.com

2 - Державне підприємство «Харківське конструкторське бюро з машинобудування імені О.О.Морозова», м. Харків, Україна 
Мета. Формалізувати залежність власних частот поступальних і крутильних коливань зчленованих вузлом з'єднання елементів конструкції вібраційної машини від ïх конструктивних параметрів і механічних характеристик, а також нормативних вимог із вібраційної активності, міцності й точності. Розробити методику вибору конструктивних параметрів стрічкового пружного елемента пакета з урахуванням заданих значень амплітудних і частотних характеристик відтворюваних несучою конструкцією динамічних навантажень і коефіцієнта варіації власних частот поступальних і крутильних коливань.

Методика. Дослідження базуються на фундаментальних підходах прикладної механіки, теорії моделювання, динаміки машин і вібраційної надійності.

Результати. Отримані та проаналізовані залежності власних частот крутильних коливань, пов'язаних вузлом з'єднання корпусних деталей вібраційної машини, від їх конструктивних параметрів і механічних характеристик. Розглядаються вібрації навколо осі, ортогональної робочому напрямку вузла. Виконано порівняльний аналіз власних частот вузла в напрямку переданої вібрації та його крутильних коливань від конструктивних параметрів і механічних характеристик стрічкових пружних елементів, їх кількості в пакеті й числа пакетів у вузлі з'єднання.

Наукова новизна. Полягає в тому, що вперше отримані залежності, що описують власні частоти поступальних і крутильних коливань корпусних деталей вібраційної машини, зчленованих пакетом стрічкових пружних елементів. Також інноваційною є парадигма до вибору конструктивних параметрів і механічних характеристик стрічкового пружного елемента пакета, що заснована на результатах порівняльного аналізу власних частот коливань у робочому та зв'язаному напрямках через коефіцієнт їх варіації. Це дозволило в методологію синтезу конструктивної схеми вібраційної машини разом із критеріями жорсткості й міцності включити критерій точності відтворення вібрації, що формалізовано через коефіцієнт варіації частот.

Практична значимість. Запропоновані методичні piшення до розрахунку й вибору конструктивних параметрів і механічних характеристик стрічкових пружних елементів забезпечують при модернізації існуючих машин і створенні нової сучасної техніки досягнення показників вібраційної активності зчленованих деталей, а також співвідношення власних частот коливань у робочому та зв'язаному напрямках на рівні вимог нормативних документів. У результаті підвищується надійність, довговічність, безпека, продуктивність і несуча здатність машин, устаткування й механізмів гірничого машинобудування, авіаційної, транспортної та космічної техніки

Ключові слова: крутильні коливання, вузли з'єднання вібростенда, вібраційні навантаження, стрічковий пружний елемент, вібраційні машини

The manuscript was submitted 16.03.21. 